\title{
Review
}

Ophthalmologica

\section{Apoptosis and Other Cell Death Mechanisms after Retinal Detachment: Implications for Photoreceptor Rescue}

\author{
Amy C.Y. Lo ${ }^{a, b}$ Tiffany T.Y. Woo ${ }^{a}$ Raymond L.M. Wonga ${ }^{a, b}$ David Wong ${ }^{a, b}$ \\ ${ }^{a}$ Eye Institute and ${ }^{b}$ Research Centre of Heart, Brain, Hormone and Healthy Ageing, Li Ka Shing Faculty of Medicine, \\ University of Hong Kong, Hong Kong, SAR, China
}

\section{Key Words}

Programmed cell death $\cdot$ Caspase $\cdot$ Mitochondria $\cdot$

Necrosis $\cdot$ Neuroprotection

\begin{abstract}
Retinal detachment (RD) is one of the most common causes of blindness. This separation of the neurosensory retina from its underlying retinal pigment epithelium results in photoreceptor loss, which is the basis of permanent visual impairment. This review explores the various cell death mechanisms in photoreceptor death associated with RD. One of the major mechanisms is apoptosis, mediated by the intrinsic pathway, the Fas signalling pathway and/or the caspase-independent pathway. Other pathways of mechanisms include endoplasmic reticulum stress-mediated cell death, programmed necrosis and cytokine-related pathways. Understanding the mechanism of RD-associated photoreceptor death is likely to help us improve the current therapies or devise new strategies for this sight-threatening condition.
\end{abstract}

Copyright $\odot 2011$ S. Karger AG, Basel

\section{Photoreceptor Apoptosis}

Photoreceptor apoptosis forms an essential part of normal visual development, with evidence suggesting a critical period of development in which photoreceptors are produced in excess and then culled to an appropriate level for adult usage [1]. These intrinsic programmes were argued to carry evolutionary advantages, in part contributing to the specificity of the adult neural circuitry [2].

Dysregulation of programmed cell death, however, has been held culprit in the pathogenesis of inborn errors, carcinogenesis and autoimmune diseases among many others. Multiple lines of evidence have shown that apoptosis is a major cause of neuronal loss after trauma, ischaemia and neurodegeneration in the central nervous system $[3,4]$. Likewise, apoptosis is a major cause of photoreceptor degeneration and neuronal loss in diverse degenerative retinal diseases [5-11] as well as various retinal pathologies including retinal ischaemia/reperfusion injury [12-14], light-induced damage [15] and following retinal detachment (RD) [16-22].

\section{Retinal Detachment}

$\mathrm{RD}$ is one of the commonest sight-threatening eye diseases. It also occurs in a variety of retinal disorders such as age-related macular degeneration, diabetic retinopathy and retinopathy of prematurity. In $\mathrm{RD}$, the outer retina (including the photoreceptors) is separated from the underlying retinal pigment epithelium, which provides the major metabolic and nutritional support for the pho-

\section{KARGER}

Fax +4161306 1234

E-Mail karger@karger.ch

www.karger.com
(C) 2011 S. Karger AG, Basel

$0030-3755 / 11 / 2265-0010 \$ 38.00 / 0$

Accessible online at:

www.karger.com/oph
Amy C.Y. Lo

Eye Institute, Li Ka Shing Faculty of Medicine

University of Hong Kong

Hong Kong, SAR (China)

E-Mail amylo@hkucc.hku.hk 
toreceptors, leading to photoreceptor death and permanent visual loss. There are three main types of $\mathrm{RD}$, including rhegmatogenous, tractional and exudative RD. Of these, rhegmatogenous $\mathrm{RD}$ is the commonest cause, affecting 6.3-17.9 per 100,000 persons per year [23]. The pathogenesis of rhegmatogenous $\mathrm{RD}$ involves the passage of liquefied vitreous under the neurosensory retina through a retinal break, which in turn separates the neurosensory retina from the underlying retinal pigment epithelium. Tractional RD is caused by proliferative retinopathy such as proliferative diabetic retinopathy; it can also be the consequence of penetrating trauma of the posterior segment. The resulting proliferative membranes of this condition contract and pull the neurosensory retina away from the underlying retinal pigment epithelium, causing a detachment. Exudative RD, on the other hand, is characterised by the accumulation of fluid in the subretinal space secondary to retinal or choroidal vascular, inflammatory or malignant diseases. $\mathrm{RD}$ of the exudative type is usually less extensive than the other two types.

Management of RD depends on the type and aetiology of the detachment. Standard methods of treatment include laser photocoagulation, pneumatic retinopexy, scleral buckling and primary vitrectomy. The treatment for rhegmatogenous RD would be surgery aiming to locate all retinal breaks, close the breaks by creating chorioretinal irritation around each break and eliminate the traction that caused the breaks. Most clinical trials have shown that there is no significant difference between the outcomes of different surgical options (pneumatic retinopexy, scleral buckling and primary vitrectomy) for rhegmatogenous $\mathrm{RD}$, though some may show a preference towards primary vitrectomy [24-29]. Prognoses of tractional and exudative RD depend on the aetiology and extent of the underlying condition.

To date, there are no effective treatments for RD-induced permanent loss of vision. Although surgery can reattach the retina and the surgical outcome is greatly improved and associated with less complications [30], visual acuity is not always restored due to photoreceptor apoptosis that continues after RD. Some patients experience visual impairment despite successful surgical reattachment. Therefore, identification of the mechanisms that underlie photoreceptor death after RD is crucial to developing new treatment strategies for retinal disease in which $\mathrm{RD}$ is a clinical feature.

\section{Apoptosis}

Apoptosis is a highly complex process regulated by a wide range of cell signals and eventually leading to DNA fragmentation and cell demolition. Much insight has been gained in recent years concerning the signalling pathways and proteins involved, but current models tend to attribute effects to the few known complexes, and many key signalling players remain to be elucidated [31].

Two major signalling cascades have been identified, namely the extrinsic and intrinsic pathways [32]. Both centrally involve the caspase family of proteins as initiators and effectors of apoptosis propagation [33]. Initiator caspases are, by definition, the first to be activated in the apoptotic pathway in context. They in turn activate effector caspases, which trigger a series of proteolytic events that eventually lead to cell death [34].

\section{The Extrinsic Pathway}

The extrinsic pathway is initiated when certain death receptors (DR) on the cell surface are activated by death ligands (DL). DR mainly comprise the tumour necrosis factor (TNF) receptor family including FAS, TNFR1 and TRAIL (TNF-related apoptosis-inducing ligand) receptor (activated by their respective DL such as FAS ligand, TNF and TRAIL) [35]. Binding of a DL to a DR results in death-inducing signalling complex formation [36], which brings together the initiator caspases of the extrinsic pathway, i.e. procaspase- 8 and procaspase-10 [37]. Cleavage of procaspase- 8 releases caspase- 8 into the cytosol to act on effector caspases.

\section{The Intrinsic Pathway}

The intrinsic pathway is triggered by a variety of factors including genotoxic stress, UV irradiation, certain hormones (e.g. glucocorticoids) and cytokine deprivation [37]. Exposure to these factors leads to mitochondrial outer membrane permeabilisation (MOMP) and eventually cytochrome $c$ release from the mitochondria into the cytosol [38]. The release of cytochrome $\mathrm{c}$ from the mitochondria is also regulated by proteins of the B-cell lymphoma 2 (Bcl-2) family. The Bcl-2 family is divided into two classes of molecules that have opposing effects: antiapoptotic members such as Bcl-2 and Bcl-xL that protect the cell against apoptosis, and proapoptotic members such as Bcl-2-associated $\mathrm{X}$ protein (Bax) and $\mathrm{Bcl}-2$ homologous antagonist/killer (Bak) that trigger apoptosis.

The apoptosome formed between released cy tochrome c, apoptosis-activating factor 1 and caspase- 9 recruits and activates the initiator caspase of the intrinsic path- 
way, procaspase-9. Cleavage of procaspase-9 liberates caspase-9, which in turn activates downstream effector caspases [39].

\section{The Final Common Pathway}

A final common pathway for both intrinsic and extrinsic cascades involves activation of the effector caspases (caspase-3, caspase- 6 and caspase-7) by caspase- 8 in the extrinsic pathway or caspase-9 in the intrinsic pathway. This then triggers cleavage of cellular proteins, nuclear shrinkage and DNA fragmentation [37].

\section{RD-Associated Photoreceptor Apoptosis}

Much progress has been made in our understanding of apoptosis and photoreceptor death. Photoreceptor apoptosis after RD was first described in humans after traumatic RD [16] and in cats after experimental RD [17]. Since then, photoreceptor apoptosis associated with RD has been extensively studied in a variety of experimental model systems [40-42] such as cats, rabbits, rodents, ground squirrels [43] and primates [44, 45]. Photoreceptor apoptosis has been correlated with retinal functional changes, and inhibition of apoptosis could limit the retinal functional loss [46].

\section{Cellular Changes after RD}

Histopathological changes following $\mathrm{RD}$ have been well documented in animal models [40-42, 47, 48] and human patients $[48,49]$. During apoptosis after RD, photoreceptors initially develop the characteristic morphological features of apoptosis, followed by a clearance process where apoptotic bodies are engulfed and digested by phagocytes [50]. The chain of molecular and cellular processes that happens in the retina after $\mathrm{RD}$ is strictly regulated and related to the signalling cascades that have been identified.

\section{Mitochondria and Intrinsic Pathway}

When proapoptotic Bax and/or Bak are activated, MOMP is triggered and leads to the release of cytochrome $c$ and hence apoptosis. In fact, increased expression of Bax has most often been implicated as a cause of cell death [51, 52], and the overexpression of Bax generally induces apoptosis. Similarly, overexpression of Bax leads to extensive rod photoreceptor death in the eye [53]. In contrast, the genetic deletion of Bax in Bax-deficient mice abolished cell loss after $\mathrm{RD}$, suggesting a critical role of the Bax-mediated apoptotic pathway in RD-associated photoreceptor death. Further evidence pointing to the involvement of the intrinsic pathway came from studies on caspases. Time-dependent activation of caspases-3, -7 and -9 was first shown in experimentally detached retina [19], indicating the involvement of caspases in photoreceptor death after RD. Yet, inhibition of caspases by the wide-range caspase inhibitor Z-VAD-fmk fails to block photoreceptor apoptosis [54], suggesting an involvement of other caspase-independent pathways.

\section{Fas Signalling Pathway}

The receptor-mediated extrinsic pathway also contributes to RD-associated photoreceptor apoptosis. Experimental RD resulted in activation of both the Fas proapoptotic pathway and the intrinsic pathway [20]. Injection of anti-FAS receptor antibody reduced caspase- 9 activity [20] as well as the number of TUNEL (terminal deoxynucleotidyl transferase-mediated dUTP nick end labelling)-positive photoreceptors, and preserved the outer nuclear layer (ONL) [21]. These results point to a beneficial effect of Fas signalling pathway inhibition in photoreceptor preservation after RD.

\section{Caspase-Independent Pathway}

It is evident that a caspase-independent pathway exists in apoptosis. MOMP causes cell death even if caspases are inhibited [55], and a wide-range caspase inhibitor, ZVAD-fmk, fails to block photoreceptor apoptosis [54]. These findings that photoreceptor apoptosis still develops when the downstream caspases are inhibited suggest a mitochondria-mediated but caspase-independent pathway for photoreceptor apoptosis. Previous research showed that apoptosis-inducing factor (AIF) is a caspaseindependent apoptotic factor. AIF is normally confined to the mitochondrial intermembrane space [56]. During apoptosis, AIF translocates to the cytosol and then to the nucleus, triggering peripheral chromatin condensation and, later, large-scale DNA degradation [56]. The mitochondrionuclear translocation of AIF was also observed after RD in experimental rats [54] and mice [22] as well as in human retinae [22], providing strong evidence of AIF contribution to RD-associated photoreceptor apoptosis.

\section{Other Pathways of RD-Associated Photoreceptor Death Mechanism}

Interestingly, recent research has shown that while apoptosis is believed to be the major cause of photoreceptor death after RD, it is not the only cause. The involve- 
ment of the apoptotic pathway is well documented; yet, inhibitors of this pathway can only partly rescue photoreceptors, suggesting the existence of other pathways for $\mathrm{RD}$-associated photoreceptor death.

\section{Endoplasmic Reticulum Stress-Mediated Cell Death}

In response to stress, disruption of endoplasmic reticulum (ER) homoeostasis - often termed 'ER stress' occurs in the cell and results in accumulation of unfolded proteins in the ER lumen $[57,58]$. ER stress is initially a self-protection mechanism; yet, prolonged or excessive ER stress can lead to ER stress-mediated cell death [59]. ER stress has been shown to be important in neuronal death in neurodegenerative disorders [60-62] as well as retinal degenerations [63-66]. In experimental RD, elevation of two ER stress markers in association with retinal cell death suggested that ER stress-mediated apoptosis is one pathway for $\mathrm{RD}$-associated photoreceptor death [67].

\section{Programmed Necrosis}

Besides apoptosis, Trichonas et al. [68] showed that there is a redundant mediator of photoreceptor death after experimental RD. When caspases are inhibited by the wide-range caspase inhibitor Z-VAD-fmk, necrosis mediated by receptor-interacting protein (RIP) kinase takes place and becomes the dominant form of photoreceptor death after RD. RIP1 is a serine/threonine kinase that forms a complex with Fas-associated death domain and caspase- 8 upon death domain receptor stimulation [69]. Consistently, there is an increased level of high-mobility group box1 protein, a factor released from necrotic cells, but not apoptotic cells, in human eyes with RD [70], confirming the existence of necrotic photoreceptor death. As RIP-mediated programmed necrosis happens in addition to apoptosis after RD and both lead to photoreceptor death, it was postulated that simultaneous inhibition of RIP kinases and caspases may be one effective strategy for photoreceptor protection after RD.

\section{Cytokines}

Cytokines are secreted protein molecules that can regulate caspase activity and therefore cell apoptosis in response to injury. In the eye, higher levels of vitreous cytokines were observed after RD [71-78]. One particular cytokine, monocyte chemoattractant protein-1 (MCP-1), has been shown to be associated with photoreceptor cell death. Increased expression and release of MCP-1 was found in detached retina $[70,79]$, while injec- tion of MCP-1-blocking antibody greatly reduced RDinduced photoreceptor apoptosis [80]. It was postulated that the chemotactic properties and possibly macrophage/microglion-generated oxidative stress might contribute to the cytotoxic effect of MCP-1 on photoreceptors after RD.

\section{Photoreceptor Rescue and Neuroprotective Strategies}

Understanding the mechanisms by which photoreceptors die may suggest strategies for rescuing the photoreceptors after RD. Several useful neuroprotective strategies including oxygen supplementation, delivery of neurotrophic factors and blockade of protein activity in the apoptotic signalling pathway have been postulated.

\section{Oxygen Supplementation}

Detachment of the outer retina from its underlying retinal pigment epithelium diminishes the source of its nutrient and oxygen. Presumably, the detached retina is hypoxic and hypoglycaemic. Indeed, oxygen supplementation (hyperoxia) was reported to reduce photoreceptor death in experimental RD, good evidence suggesting that oxygen supplementation between diagnosis and surgery will improve outcomes [1,81-83].

\section{Neurotrophic Factors}

Neurotrophic factors have been shown to be important in photoreceptor rescue [18]. The first experimental success was the use of basic fibroblast growth factor in the Royal College of Surgeons rat [84]. Other neurotrophic factors such as brain-derived neurotrophic factor (BDNF) [85], nerve growth factor (NGF) $[86,87]$ and glial cell line-derived neurotrophic factor (GDNF) [88] have also been shown to be useful in experimental RD. Intravitreal injection of recombined NGF increased the number of nuclei in the ONL while decreasing the number of TUNEL-positive cells [86, 87]. In general, long-term maintenance of high levels is desired for photoreceptor rescue and survival. Yet, the short half-life of these agents means repeated intravitreal injection, which is impractical and causes undesirable side effects. Alternatively, a transfection agent containing sequences coding for the desired protein can be used instead. Gene delivery of GDNF by recombinant adeno-associated virus was tested and resulted in a thicker ONL and less apoptotic cells in the photoreceptor layer [88]. 
Table 1. Agents which reduced the extent of photoreceptor apoptosis in animal models after RD

\begin{tabular}{|c|c|c|}
\hline BDNF [85] & $\begin{array}{l}\text { Maintain surviving photoreceptors; } \\
\text { reduce Müller gliosis; } \\
\text { promote outer segment regeneration (?) }\end{array}$ & Cat \\
\hline BDNF [54] & - & Brown Norway rats \\
\hline Fas receptor-neutralising antibody $[20,21]$ & - & Brown Norway rats \\
\hline NGF $[86,87]$ & Prevent apoptosis & Sprague-Dawley rats \\
\hline MCP-1 $[80]$ & $\begin{array}{l}\text { Chemotactic effect on macrophages/ } \\
\text { microglia and macrophage/ } \\
\text { microglion-generated oxidative stress }\end{array}$ & $\begin{array}{l}\mathrm{MCP}-1^{-/-} \text {mice; } \\
\mathrm{Mac}-1^{-/-} \text {mice; } \\
\text { C57BL/ } 6 \text { mice }\end{array}$ \\
\hline $\begin{array}{l}\text { Recombinant adeno-associated virus vector } \\
\text { expressing heme oxygenase } 1 \text { [91] }\end{array}$ & - & Sprague-Dawley rats \\
\hline Interleukin-6 [92] & - & $\begin{array}{l}\text { Wild-type C57BL mice; } \\
\text { IL-6 } 6^{-1-} \text { mice; } \\
\text { Brown Norway rats }\end{array}$ \\
\hline $\begin{array}{l}\text { Recombinant adeno-associated virus encoding } \\
\text { X-linked inhibitor of apoptosis [93] }\end{array}$ & - & Brown Norway rats \\
\hline Palomid 529 [94] & $\begin{array}{l}\text { Inhibit Akt/mammalian target of } \\
\text { rapamycin pathway }\end{array}$ & $\begin{array}{l}\text { New Zealand red } \\
\text { pigmented rabbits }\end{array}$ \\
\hline
\end{tabular}

$\mathrm{bFGF}=$ Basic fibroblast growth factor; GFP = green fluorescent protein.

\section{Apoptosis-Based Therapies}

Interfering directly with the apoptotic pathway is appealing, given the extensive research showing that apoptosis is ubiquitous and occurs virtually in every cell type. Apoptotic cell death is the main cause of photoreceptor death after RD. Manipulation of the various signalling pathways in apoptosis is neuroprotective; it can decrease the number of dead retinal cells and may therefore prevent the irreversible loss of visual function. The involvement of the intrinsic, extrinsic and caspase-independent pathways has helped to identify potential therapeutic tar- gets. These include Bax [89], Fas receptor/ligand [20, 21, $90]$ and AIF $[22,54]$. A summary of the potential therapeutic agents tested is provided in table 1.

\section{Conclusion}

Understanding the pathogenesis of RD is of great clinical significance. Manipulation of photoreceptor apoptosis provides a logical strategy for protecting photoreceptors. Administration of a drug that can prevent pho- 
toreceptor death and loss between onset of $\mathrm{RD}$ and reattachment surgery would be highly desirable. Tremendous efforts have been undertaken to identify potential therapeutic targets for the prevention of visual loss in various retinal disorders associated with RD.

\section{Disclosure Statement}

The authors report no proprietary or commercial interest in any concept discussed in this article.

\section{References}

$>_{1}$ Stone J, Maslim J, Valter-Kocsi K, Mervin K, $>13$ Li SY, Fu ZJ, Ma H, Jang WC, So KF, Wong Bowers F, Chu Y, Barnett N, Provis J, Lewis G, Fisher SK, Bisti S, Gargini C, Cervetto L, Merin S, Peer J: Mechanisms of photoreceptor death and survival in mammalian retina. Prog Retin Eye Res 1999;18:689-735.

2 Voyvodic JT: Cell death in cortical development: how much? Why? So what? Neuron 1996; 16:693-696.

3 Martin LJ: Neuronal cell death in nervous system development, disease, and injury. Int J Mol Med 2001;7:455-478.

4 Vila M, Przedborski S: Targeting programmed cell death in neurodegenerative diseases. Nat Rev Neurosci 2003;4:365-375.

5 Shahinfar S, Edward DP, Tso MO: A pathologic study of photoreceptor cell death in retinal photic injury. Curr Eye Res 1991;10:4759.

6 Chang GQ, Hao Y, Wong F: Apoptosis: final common pathway of photoreceptor death in $r d, r d s$, and rhodopsin mutant mice. Neuron 1993; 11:595-605.

7 Portera-Cailliau C, Sung CH, Nathans J, Adler R: Apoptotic photoreceptor cell death in mouse models of retinitis pigmentosa. Proc Natl Acad Sci USA 1994;91:974-978.

${ }_{8}$ Tso MO, Zhang C, Abler AS, Chang CJ, Wong F, Chang GQ, Lam TT: Apoptosis leads to photoreceptor degeneration in inherited retinal dystrophy of RCS rats. Invest Ophthalmol Vis Sci 1994;35:2693-2699.

9 Gregory CY, Bird AC: Cell loss in retinal dystrophies by apoptosis: death by informed consent! Br J Ophthalmol 1995;79:186-190.

10 Smith SB, Bora N, McCool D, Kutty G, Wong P, Kutty RK, Wiggert B: Photoreceptor cells in the vitiligo mouse die by apoptosis: TRPM-2/clusterin expression is increased in the neural retina and in the retinal pigment epithelium. Invest Ophthalmol Vis Sci 1995; 36:2193-2201.

$11 \mathrm{Xu}$ GZ, Li WW, Tso MO: Apoptosis in human retinal degenerations. Trans Am Ophthalmol Soc 1996;94:411-430, discussion 430-431.

12 Cheung AK, Lo AC, So KF, Chung SS, Chung SK: Gene deletion and pharmacological inhibition of aldose reductase protect against retinal ischemic injury. Exp Eye Res 2007;85 608-616.

RD-Associated Photoreceptor Cell Death
D, Lo AC: Effect of lutein on retinal neurons and oxidative stress in a model of acute retinal ischemia/reperfusion. Invest Ophthalmol Vis Sci 2009;50:836-843.

14 Li SY, Yang D, Yeung CM, Yu WY, Chang RC, So KF, Wong D, Lo AC: Lycium barbarum polysaccharides reduce neuronal damage, blood-retinal barrier disruption and oxidative stress in retinal ischemia/reperfusion injury. PLoS One 2011;6:e16380.

- 15 Hafezi F, Steinbach JP, Marti A, Munz K, Wang ZQ, Wagner EF, Aguzzi A, Remé CE: The absence of c-fos prevents light-induced apoptotic cell death of photoreceptors in retinal degeneration in vivo. Nat Med 1997;3: 346-349.

16 Chang CJ, Lai WW, Edward DP, Tso MO: Apoptotic photoreceptor cell death after traumatic retinal detachment in humans. Arch Ophthalmol 1995;113:880-886.

17 Cook B, Lewis GP, Fisher SK, Adler R: Apoptotic photoreceptor degeneration in experimental retinal detachment. Invest Ophthalmol Vis Sci 1995;36:990-996.

18 Luthert PJ, Chong NH: Photoreceptor rescue. Eye (Lond) 1998;12:591-596.

19 Zacks DN, Hanninen V, Pantcheva M, Ezra E, Grosskreutz C, Miller JW: Caspase activation in an experimental model of retinal detachment. Invest Ophthalmol Vis Sci 2003; 44:1262-1267.

20 Zacks DN, Zheng QD, Han Y, Bakhru R, Miller JW: FAS-mediated apoptosis and its relation to intrinsic pathway activation in an exvest Ophthalmol Vis Sci 2004;45:4563-4569.

21 Zacks DN, Boehlke C, Richards AL, Zheng QD: Role of the Fas-signaling pathway in photoreceptor neuroprotection. Arch Ophthalmol 2007;125:1389-1395.

-22 Hisatomi T, Nakazawa T, Noda K, Almulki L, Miyahara S, Nakao S, Ito Y, She H, Kohno R, Michaud N, Ishibashi T, Hafezi-Moghadam A, Badley AD, Kroemer G, Miller JW: HIV protease inhibitors provide neuroprotection through inhibition of mitochondrial apoptosis in mice. J Clin Invest 2008;118: 2025-2038.

23 Mitry D, Charteris DG, Fleck BW, Campbell $\mathrm{H}$, Singh J: The epidemiology of rhegmatogenous retinal detachment: geographical variation and clinical associations. Br J Ophthalmol 2010;94:678-684. perimental model of retinal detachment. In-
24 Tornambe PE, Hilton GF: Pneumatic retinopexy: a multicenter randomized controlled clinical trial comparing pneumatic retinopexy with scleral buckling. The Retinal Detachment Study Group. Ophthalmology 1989;96:772-783, discussion 784.

25 Mulvihill A, Fulcher T, Datta V, Acheson R: Pneumatic retinopexy versus scleral buckling: a randomised controlled trial. Ir J Med Sci 1996; 165:274-277.

-26 Ahmadieh H, Moradian S, Faghihi H, Parvaresh MM, Ghanbari H, Mehryar M, Heidari E, Behboudi H, Banaee T, Golestan B: Anatomic and visual outcomes of scleral buckling versus primary vitrectomy in pseudophakic and aphakic retinal detachment: sixmonth follow-up results of a single operation - report No 1. Ophthalmology 2005;112: 1421-1429.

-27 Brazitikos PD, Androudi S, Christen WG, Stangos NT: Primary pars plana vitrectomy versus scleral buckle surgery for the treatment of pseudophakic retinal detachment: a randomized clinical trial. Retina 2005;25: 957-964.

28 Sharma YR, Karunanithi S, Azad RV, Vohra R, Pal N, Singh DV, Chandra P: Functional and anatomic outcome of scleral buckling versus primary vitrectomy in pseudophakic retinal detachment. Acta Ophthalmol Scand 2005;83:293-297.

29 Heimann H, Bartz-Schmidt KU, Bornfeld N, Weiss C, Hilgers RD, Foerster MH: Scleral buckling versus primary vitrectomy in rhegmatogenous retinal detachment: a prospective randomized multicenter clinical study. Ophthalmology 2007;114:2142-2154.

30 Brazitikos PD: The expanding role of primary pars plana vitrectomy in the treatment of rhegmatogenous noncomplicated retinal detachment. Semin Ophthalmol 2000;15:6577.

31 Lavrik IN: Systems biology of apoptosis signaling networks. Curr Opin Biotechnol 2010;21:551-555.

32 Krammer PH: CD95's deadly mission in the immune system. Nature 2000;407:789-795.

33 Lavrik IN, Golks A, Krammer PH: Caspases: pharmacological manipulation of cell death. J Clin Invest 2005; 115:2665-2672.

34 Fuentes-Prior P, Salvesen GS: The protein structures that shape caspase activity, specificity, activation and inhibition. Biochem J 2004;384:201-232. 
35 Ashkenazi A, Dixit VM: Death receptors: signaling and modulation. Science 1998;281: 1305-1308.

- 36 Kischkel FC, Hellbardt S, Behrmann I, Germer M, Pawlita M, Krammer PH, Peter ME: Cytotoxicity-dependent APO-1 (Fas/ CD95)-associated proteins form a death-inducing signaling complex (DISC) with the receptor. EMBO J 1995;14:5579-5588.

37 Krammer PH, Arnold R, Lavrik IN: Life and death in peripheral $\mathrm{T}$ cells. Nat Rev Immunol 2007;7:532-542.

- 38 Green DR, Kroemer G: The pathophysiology of mitochondrial cell death. Science 2004; 305:626-629.

- 39 Brenner D, Mak TW: Mitochondrial cell death effectors. Curr Opin Cell Biol 2009;21: 871-877.

-40 Lewis GP, Charteris DG, Sethi CS, Fisher SK: Animal models of retinal detachment and reattachment: identifying cellular events that may affect visual recovery. Eye (Lond) 2002;16:375-387.

-41 Lewis GP, Sethi CS, Linberg KA, Charteris DG, Fisher SK: Experimental retinal reattachment: a new perspective. Mol Neurobiol 2003;28:159-175.

-42 Fisher SK, Lewis GP, Linberg KA, Verardo MR: Cellular remodeling in mammalian retina: results from studies of experimental retinal detachment. Prog Retin Eye Res 2005; 24:395-431.

-43 Linberg KA, Sakai T, Lewis GP, Fisher SK: Experimental retinal detachment in the cone-dominant ground squirrel retina: morphology and basic immunocytochemistry. Vis Neurosci 2002;19:603-619.

-44 Kroll AJ, Machemer R: Experimental retinal detachment in the owl monkey. V. Electron microscopy of the reattached retina. Am J Ophthalmol 1969;67:117-130.

-45 Guerin CJ, Anderson DH, Fariss RN, Fisher SK: Retinal reattachment of the primate macula: photoreceptor recovery after shortterm detachment. Invest Ophthalmol Vis Sci 1989;30:1708-1725.

46 Hisatomi T, Sakamoto T, Goto Y, Yamanaka I, Oshima Y, Hata Y, Ishibashi T, Inomata H, Susin SA, Kroemer G: Critical role of photoreceptor apoptosis in functional damage after retinal detachment. Curr Eye Res 2002; 24:161-172.

-47 Kubay OV, Charteris DG, Newland HS, Raymond GL: Retinal detachment neuropathology and potential strategies for neuroprotection. Surv Ophthalmol 2005;50:463-475.

48 Wickham L, Charteris DG: Glial cell changes of the human retina in proliferative vitreoretinopathy. Dev Ophthalmol 2009;44:3745.

49 Wickham L, Sethi CS, Lewis GP, Fisher SK, McLeod DC, Charteris DG: Glial and neural response in short-term human retinal detachment. Arch Ophthalmol 2006;124: 1779-1782.
50 Hisatomi T, Sakamoto T, Sonoda KH, Tsutsumi C, Qiao $H$, Enaida $H$, Yamanaka I, Kubota T, Ishibashi T, Kura S, Susin SA, Kroemer G: Clearance of apoptotic photoreceptors: elimination of apoptotic debris into the subretinal space and macrophage-mediated phagocytosis via phosphatidylserine receptor and integrin $\alpha_{\mathrm{v}} \beta_{3}$. Am J Pathol 2003; 162:1869-1879.

51 Oltvai ZN, Milliman CL, Korsmeyer SJ: Bcl2 heterodimerizes in vivo with a conserved homolog, Bax, that accelerates programmed cell death. Cell 1993;74:609-619.

52 MacGibbon GA, Lawlor PA, Sirimanne ES, Walton MR, Connor B, Young D, Williams C, Gluckman P, Faull RL, Hughes P, Dragunow $\mathrm{M}$ : Bax expression in mammalian neurons undergoing apoptosis, and in Alzheimer's disease hippocampus. Brain Res 1997; 750:223-234.

53 Eversole-Cire P, Chen J, Simon MI: Bax is not the heterodimerization partner necessary for sustained anti-photoreceptor-cell-death activity of Bcl-2. Invest Ophthalmol Vis Sci 2002;43:1636-1644.

54 Hisatomi T, Sakamoto T, Murata T, Yamanaka I, Oshima Y, Hata Y, Ishibashi T, Inomata H, Susin SA, Kroemer G: Relocalization of apoptosis-inducing factor in photoreceptor apoptosis induced by retinal detachment in vivo. Am J Pathol 2001;158:1271-1278.

55 Bouchier-Hayes L, Lartigue L, Newmeyer DD: Mitochondria: pharmacological manipulation of cell death. J Clin Invest 2005;115: 2640-2647.

- 56 Susin SA, Lorenzo HK, Zamzami N, Marzo I, Snow BE, Brothers GM, Mangion J, Jacotot E, Costantini P, Loeffler M, Larochette N, Goodlett DR, Aebersold R, Siderovski DP, Penninger JM, Kroemer G: Molecular characterization of mitochondrial apoptosis-inducing factor. Nature 1999;397:441-446.

57 Harding HP, Zhang Y, Ron D: Protein translation and folding are coupled by an endoplasmic-reticulum-resident kinase. Nature 1999;397:271-274.

58 Patil CK, Li H, Walter P: Gcn $4 p$ and novel upstream activating sequences regulate targets of the unfolded protein response. PLoS Biol 2004;2:E246.

59 Momoi T: Caspases involved in ER stressmediated cell death. J Chem Neuroanat 2004:28:101-105.

60 Lindholm D, Wootz H, Korhonen L: ER stress and neurodegenerative diseases. Cell Death Differ 2006;13:385-392.

61 Sekine Y, Takeda K, Ichijo H: The ASK1MAP kinase signaling in ER stress and neurodegenerative diseases. Curr Mol Med 2006;6:87-97.

62 Yoshida H: ER stress and diseases. FEBS J 2007;274:630-658.
63 Roybal CN, Marmorstein LY, Vander Jagt DL, Abcouwer SF: Aberrant accumulation of fibulin-3 in the endoplasmic reticulum leads to activation of the unfolded protein response and VEGF expression. Invest Ophthalmol Vis Sci 2005;46:3973-3979.

64 Ryoo HD, Domingos PM, Kang MJ, Steller H: Unfolded protein response in a Drosophila model for retinal degeneration. EMBO J 2007;26:242-252.

65 Shimazawa M, Ito Y, Inokuchi Y, Hara H: Involvement of double-stranded RNA-dependent protein kinase in ER stress-induced retinal neuron damage. Invest Ophthalmol Vis Sci 2007;48:3729-3736.

66 Shimazawa M, Inokuchi Y, Ito Y, Murata H, Aihara M, Miura M, Araie M, Hara H: Involvement of ER stress in retinal cell death. Mol Vis 2007;13:578-587.

-67 Liu H, Qian J, Wang F, Sun X, Xu X, Xu W, Zhang X: Expression of two endoplasmic reticulum stress markers, GRP78 and GADD153, in rat retinal detachment model and its implication. Eye (Lond) 2010;24:137144.

68 Trichonas G, Murakami Y, Thanos A, Morizane Y, Kayama M, Debouck CM, Hisatomi T, Miller JW, Vavvas DG: Receptorinteracting protein kinases mediate retinal detachment-induced photoreceptor necrosis and compensate for inhibition of apoptosis. Proc Natl Acad Sci USA 2010;107: 21695-21700.

69 Festjens N, Vanden Berghe T, Cornelis S, Vandenabeele P: RIP1, a kinase on the crossroads of a cell's decision to live or die. Cell Death Differ 2007;14:400-410.

-70 Arimura N, Ki-i Y, Hashiguchi T, Kawahara K, Biswas KK, Nakamura M, Sonoda Y, Yamakiri K, Okubo A, Sakamoto T, Maruyama I: Intraocular expression and release of highmobility group box 1 protein in retinal detachment. Lab Invest 2009;89:278-289.

71 Abu el-Asrar AM, van Damme J, Put W, Veckeneer M, Dralands L, Billiau A, Missotten L: Monocyte chemotactic protein-1 in proliferative vitreoretinal disorders. Am J Ophthalmol 1997;123:599-606.

72 Capeans C, de Rojas MV, Lojo S, Salorio MS: $\mathrm{C}-\mathrm{C}$ chemokines in the vitreous of patients with proliferative vitreoretinopathy and proliferative diabetic retinopathy. Retina 1998;18:546-550.

73 Cassidy L, Barry P, Shaw C, Duffy J, Kennedy $S$ : Platelet derived growth factor and fibroblast growth factor basic levels in the vitreous of patients with vitreoretinal disorders. Br J Ophthalmol 1998;82:181-185.

74 El-Ghrably IA, Dua HS, Orr GM, Fischer D, Tighe PJ: Detection of cytokine mRNA production in infiltrating cells in proliferative vitreoretinopathy using reverse transcription polymerase chain reaction. $\mathrm{Br} \mathrm{J}$ Ophthalmol 1999;83:1296-1299. 
75 Kon CH, Occleston NL, Aylward GW, Khaw PT: Expression of vitreous cytokines in proliferative vitreoretinopathy: a prospective study. Invest Ophthalmol Vis Sci 1999;40: 705-712.

76 la Heij EC, van de Waarenburg MP, Blaauwgeers HG, Kessels AG, de Vente J, Liem AT, Steinbusch H, Hendrikse F: Levels of basic fibroblast growth factor, glutamine synthetase, and interleukin- 6 in subretinal fluid from patients with retinal detachment. Am J Ophthalmol 2001;132:544-550.

-77 Limb GA, Daniels JT, Pleass R, Charteris DG, Luthert PJ, Khaw PT: Differential expression of matrix metalloproteinases 2 and 9 by glial Müller cells: response to soluble and extracellular matrix-bound tumor necrosis factor- $\alpha$. Am J Pathol 2002;160:1847 1855.

-78 Mitamura Y, Takeuchi S, Yamamoto S, Yamamoto T, Tsukahara I, Matsuda A, Tagawa Y, Mizue Y, Nishihira J: Monocyte chemotactic protein-1 levels in the vitreous of patients with proliferative vitreoretinopathy. Jpn J Ophthalmol 2002;46:218-221.

79 Nakazawa T, Matsubara A, Noda K, Hisatomi T, She H, Skondra D, Miyahara S, Sobrin L, Thomas KL, Chen DF, Grosskreutz CL, Hafezi-Moghadam A, Miller JW: Characterization of cytokine responses to retinal detachment in rats. Mol Vis 2006;12:867-878.

80 Nakazawa T, Hisatomi T, Nakazawa C, Noda K, Maruyama K, She H, Matsubara A, Miyahara S, Nakao S, Yin Y, Benowitz L, HafeziMoghadam A, Miller JW: Monocyte chemoattractant protein 1 mediates retinal detachment-induced photoreceptor apoptosis. Proc Natl Acad Sci USA 2007;104:24252430.
81 Lewis G, Mervin K, Valter K, Maslim J, Kappel PJ, Stone J, Fisher S: Limiting the proliferation and reactivity of retinal Müller cells during experimental retinal detachment: the value of oxygen supplementation. Am J Ophthalmol 1999;128:165-172.

82 Mervin K, Valter K, Maslim J, Lewis G, Fisher S, Stone J: Limiting photoreceptor death and deconstruction during experimental retinal detachment: the value of oxygen supplementation. Am J Ophthalmol 1999;128: 155-164.

83 Sakai T, Lewis GP, Linberg KA, Fisher SK: The ability of hyperoxia to limit the effects of experimental detachment in cone-dominated retina. Invest Ophthalmol Vis Sci 2001; 42:3264-3273.

84 Faktorovich EG, Steinberg RH, Yasumura D, Matthes MT, LaVail MM: Photoreceptor degeneration in inherited retinal dystrophy delayed by basic fibroblast growth factor. $\mathrm{Na}$ ture 1990;347:83-86.

85 Lewis GP, Linberg KA, Geller SF, Guerin CJ, Fisher SK: Effects of the neurotrophin brainderived neurotrophic factor in an experimental model of retinal detachment. Invest Ophthalmol Vis Sci 1999;40:1530-1544.

86 Sun X, Xu X, Wang F, Zhang X, Ho PC, Liu H, Qian J, Yu Z, Lu H, Xu W: Nerve growth factor helps protect retina in experimental retinal detachment. Ophthalmologica 2008; 222:58-61

87 Sun X, Xu X, Wang F, Zhang X, Yu Z, Lu H, Ho PC: Effects of nerve growth factor for retinal cell survival in experimental retinal detachment. Curr Eye Res 2007;32:765-772.

88 Wu WC, Lai CC, Chen SL, Xiao X, Chen TL, Tsai RJ, Kuo SW, Tsao YP: Gene therapy for detached retina by adeno-associated virus vector expressing glial cell line-derived neurotrophic factor. Invest Ophthalmol Vis Sci 2002;43:3480-3488.
89 Yang L, Bula D, Arroyo JG, Chen DF: Preventing retinal detachment-associated photoreceptor cell loss in Bax-deficient mice. Invest Ophthalmol Vis Sci 2004;45:648-654.

90 Besirli CG, Chinskey ND, Zheng QD, Zacks DN: Inhibition of retinal detachment-induced apoptosis in photoreceptors by a small peptide inhibitor of the Fas receptor. Invest Ophthalmol Vis Sci 2010;51:2177-2184.

91 Shyong MP, Lee FL, Hen WH, Kuo PC, Wu AC, Cheng HC, Chen SL, Tung TH, Tsao YP: Viral delivery of heme oxygenase-1 attenuates photoreceptor apoptosis in an experimental model of retinal detachment. Vision Res 2008;48:2394-2402.

\$92 Chong DY, Boehlke CS, Zheng QD, Zhang L, Han Y, Zacks DN: Interleukin-6 as a photoreceptor neuroprotectant in an experimental model of retinal detachment. Invest Ophthalmol Vis Sci 2008;49:3193-3200.

-93 Zadro-Lamoureux LA, Zacks DN, Baker AN, Zheng QD, Hauswirth WW, Tsilfidis C: XIAP effects on retinal detachment-induced photoreceptor apoptosis [corrected]. Invest Ophthalmol Vis Sci 2009;50:1448-1453.

94 Lewis GP, Chapin EA, Byun J, Luna G, Sherris D, Fisher SK: Müller cell reactivity and photoreceptor cell death are reduced after experimental retinal detachment using an inhibitor of the Akt/mTOR pathway. Invest Ophthalmol Vis Sci 2009;50:4429-4435.

95 Yang L, Kim JH, Kovacs KD, Arroyo JG, Chen DF: Minocycline inhibition of photoreceptor degeneration. Arch Ophthalmol 2009;127:1475-1480.

-96 Otsuka H, Arimura N, Sonoda S, Nakamura M, Hashiguchi T, Maruyama I, Nakao S, Hafezi-Moghadam A, Sakamoto T: Stromal cell-derived factor-1 is essential for photoreceptor cell protection in retinal detachment. Am J Pathol 2010;177:2268-2277. 